\title{
PENDIDIKAN VOKASIONAL DALAM TINGKAT SMP SEBAGAI UPAYA MEMPERCEPAT PEMENUHAN TENAGA AHLI ABAD 21 Miftakhuddin ${ }^{1}$
}

Universitas Jember

e-mail : tuplick110@ymail.com

\section{ABSTRAK}

Perkembangan IPTEKS selalu diiringi dengan pertambahan kebutuhan dan berdampak pada penetrasi tenaga kerja, investasi dan teknologi. Saat ini liberalisasi pasar dan kerjasama regional tidak terhindarkan. Faktanya, negara paling banyak mengalami penetrasi adalah negara dengan SDA melimpah (Indonesia). Indonesia sudah mempersiapkan pembangunan infrastruktur dan penetapan kebijakan ekonomi, namun kurang fokus pada investasi melalui pendidikan vokasi. Pendidikan vokasional berorientasi pada pemenuhan kebutuhan masyarakat dibidang industri dan usaha. Pendidikan vokasional penting karena era perdagangan bebas membutuhkan tenaga ahli. Di Indonesia pendidikan vokasi dimulai pada tingkat SMU dengan PSG 4 bulan, sistem ini tidak efektif karena praktik hanya sebentar. Akan lebih efektif jika pendidikan vokasi dimulai pada jenjang SMP, dengan PSG mulai kelas satu sampai lulus (sistem pembelajaran 50:50), tujuannya adalah membuat aktivitas belajar siswa menjadi aplikatif langsung dengan konsep dasar learning by doing. Dengan kata lain pendidikan vokasional sejak pendidikan menengah pertama seperti ini akan mempercepat pemenuhan kebutuhan akan tenaga ahli.

Kata kunci : perdagangan bebas, pendidikan vokasional, SDA, tenaga ahli.

\section{VOCATIONAL EDUCATION IN JUNIOR SCHOOL LEVEL AS EFFORT TO FULFILL EXPERTS AT 21ST CENTURY}

\begin{abstract}
The development of science and technology is accompanied by increase in the need and impact on the penetration of labor, investment and technology. Currently, market liberalization and regional cooperation is inevitable. In fact, most countries experienced penetration is a country with abundant natural resources (Indonesia). Indonesia has prepared infrastructure development and establishment of economic policy, but less focus on the investment through vocational education. Vocational education oriented to the needs of people in industry and business. Vocational education is important because the free trade era requires expertise. In Indonesia, the vocational education began in high school with PSG 4 months, the system is not effective because the practice only briefly. It would be more effective if the vocational education began in junior high school, with PSG started first grade until graduation (50:50 learning system), the goal is to make students' learning activities be applied directly to the basic concept of learning by doing. In other words, vocational education from secondary education as this will accelerate the fulfillment of the need for expert.
\end{abstract}

Keywords : free trade, vocatioanl education, natural resources, experts

\footnotetext{
${ }^{1}$ Mahasiswa Jurusan Ilmu Pendidikan (angkatan 2012) - Fakultas Keguruan dan Ilmu Pendidikan Universitas Jember.
} 


\section{PENDAHULUAN}

\section{Era perdagangan bebas dan penetrasi tenaga kerja antar negara}

Perkembangan IPTEKS dapat dipastikan selalu diikuti dengan semakin bertambahnya kebutuhan yang harus dipenuhi, jika perkembangan IPTEKS ini melingkupi seluruh masyarakat dunia, maka pemenuhan kebutuhan yang harus dilakukan juga harus melibatkan seluruh masyarakat dunia, temasuk Indonesia. Pola hidup masyarakat dari tradisional yang berorientasi pada pemenuhan kebutuhan sendiri sudah beralih menjadi masyarakat dengan pola hidup industri, dimana negara bersaing untuk menghasilkan produk baru dan solutif untuk memenuhi kebutuhan masyarakat dalam lingkup yang lebih luas. Perubahan pola hidup masyarakat global menjadi produktif dimulai ketika revolusi industri.. Revolusi industri dimulai oleh Inggris pada tahun 1750 dengan mayoritas masyarakatnya usaha home industry (masih untuk memenuhi kebutuhan rumah tangga sendiri), kemudian pada tahun 1785 terjadi penemuan mesin pemintal benang, dan disusul penemuan mesin uap secara sempurna oleh James Watt pada tahun 1788. Disinilah benih atas masyarakat industri mulai tumbuh, perkembangan teknologi oleh Inggris mengawali dunia untuk memasuki babak baru dalam peradaban manusia dengan mesin. Dari sini jelas bahwa ilmu pengetahuan berkambang pesat di Inggris pada masa itu, sehingga banyak pelajar internasional yang datang kesana untuk belajar dari ahlinya menciptakan alat. Kondisi Inggri pada revolusi industri hanya membutuhkan tenaga mesin dan tenaga ahli, sehingga tenaga manusia (bukan ahli) sangat murah.

Berawal dari berbagai penemuan, Inggris mendominasi perdagangan antar negara karena pada masa itu hanya Inggris yang memiliki teknologi mutakhir. Baik alat (teknologi temuan) maupun produknya disebarkan kesemua daerah jajahan Inggris yang pada masa itu daerah jajahan Inggris sangat banyak, sehingga negara jajahan Inggris menjadi sangat produktif karena peralatan dapat mempercepat kinerja. Kerjasama anatarnegara dan memenfaatkan negara jajahan dapat menjamin kesejahtaraan masyarakat Inggris secara moril maupun materiil. Sampai sekarang negara bekas jajahan masih konsumtif atas teknologi mutakhir. 
Indonesia merupakan salah satu negara berkembang yang pada saat ini giat membangun segala sektor pembangunan khususnya sektor industri. Untuk melaksanakan pembangunan ini diperlukan manusia yang cerdas, profesional di bidangnya masing-masing dalam berbagai aspek kehidupan, terampil, memiliki etos kerja yang tinggi, serta bertanggung jawab atas pembangunan bangsa. (Aditya,2009). Untuk menjadi negara maju yang bisa mendominasi pasar internasional, maka Indonesia harus mau bercermin pada Inggris dengan membandingkan mutu SDM yang dimiliki. Salah satu kunci dari kemajuan perekonomian Inggris adalah kepemilikan atas tenaga ahli dari segi kuantitas maupun kualitas. Dalam 10 tahun ke depan, Indonesia diprediksi menjadi salah satu motor penggerak pertumbuhan ekonomi dunia. Maka, pengembangan industri di Indonesia diperkirakan meningkat tajam sehingga sangat dibutuhkan tenagatenaga terampil untuk mengisi kebutuhan industri dalam berbagai bidang (Yuhanis,2013). Jika Indonesia tidak punya SDM yang mampu mengolah SDA milik sendiri, maka Indonesia akan menjadi buruh di rumahnya sendiri karena SDA yang dimiliki Indonesia diolah oleh tenaga ahli bangsa asing, dan yang lebih parah lagi Indonesia bukannya mengekspor produk tapi justru mengekspor buruh. Ini adalah fakta yang sedang dihadapi, Indonesia dihadapkan pada dua pilihan, yaitu meningkatkan kualias SDM atau menjadi buruh di negara lain. 


\section{METODE}

Metode yang digunakan dalam penulisan artikel ini adalah dengan pengamatan langsung (obeservasi) terhadap subjek penelitian dan kajian pustaka dari berbagaia sumber, berupa jurnal ilmiah dan artikel ilmiah. Subjek yang diobservasi oleh penulis adalah masyarakat yang ada dilingkungan penulis sendiri, sehingga lebih akurat dan efektif. Sedangakan metode kajian pustaka dimaksud dilakukan degan mencari referensi di perpustakaan dan download file melalui website. Pemilihan metode didasarkan pada waktu yang tersedia untuk menyelesaikan artikel ilmiah dan kapabilitas penulis dalam penggarapannya. Kedua metode ini dipilih karena merupakan metode yang paling mudah dan tidak memakan waktu yang relatif lama. Selain atas dasar kerumitan dan efisiensi waktu, jurnal ilmiah dan artikel ilmiah dipilih karena memiliki akurasi dan relevansi yang lebih kuat, karena berdasarkan tinjauan ilmiah. Dalam pelaksanaannya, observasi dilakukan terlebih dahulu untuk memastikan bahwa masalah yang diangkat dalam artikel ini patut untuk diteliti, setelah dirasa yakin mengenai masalah yang akan diteliti, kemudian merumuskan hipotesis secara eksplisit yang akan dijadikan acuan dalam langkah penelitian yang selanjutnya.

Langkah berikutnya adalah melakukan kajian pustaka dari berbagai sumber berupa jurnal ilmiah dan artikel ilmiah baik dalam bentuk hardcopy maupun softcopy. Kajian pustaka ini dilakukan hanya pada karya-karya yang telah dipublikasikan 5 tahun terkakhir, hal ini dimaksdkan untuk kepentingan validitas atau relevansi masalah yang sedang diteliti. Dengan demikian masalah yang sedang diteliti masih terglong baru. 


\section{HASIL DAN PEMBAHASAN}

\section{Kondisi sekolah kejuruan}

Menurut Abdulloh (2013), SMK mempunyai ciri khas yang membedakan dengan sekolah menengah atas lainnya (SMA dan MA) yaitu hubungan erat dengan dunia kerja. Sekolah kejuruan dipilih oleh masyarakat sebagai instansi pendidikan yang dipercaya dapat menjamin lapangan kerja. Sekolah kejuruan memberi jaminan akan tenaga ahli dibidang industri dan usaha.

Depdiknas memiliki kebijakan untuk membalik rasio peserta didik SMK dibanding SMA dari 30:70 pada tahun 2004, menjadi 67:33 pada tahun 2014. Kebijakan ini ditujukan agar keluaran pendidikan dapat lebih berorentasi pada pemenuhan dunia kerja serta kebutuhan dunia usaha dan industri(DUDI). Pendidikan vokasi dirasa perlu karena memiliki paradigma yang menekankan pada pendidikan yang menyesuaikan dengan permintaan pasar (demand driven) guna mendukung pembangunan ekonomi kreatif. Ketersambungan (link) diantara pengguna lulusan pendidikan dan penyelenggara pendidikan dan kecocokan (match) antara employee dengan employer menjadi dasar penyelenggaraan pendidikan vokasi. Keberhasilan penyelenggaraan pendidikan vokasi dapat dilihat dari tingkat mutu dan relevansi yaitu jumlah penyerapan lulusan dan kesesuaian bidang. (Depdiknas, Renstra 2010 - 2014, 83-85, dalam Bambang, 2011).

Dalam kaitannya dengan pertumbuhan ekonomi, pendidikan vokasional merupakan pencetak kontributor tenaga ahli pada era industrialisasi. Fakta saat ini adalah pendidikan vokasioanl dimulai pada tingkat sekolah menengah umum dengan PSG untuk kelas XI selama kurang lebih 4 bulan.

\section{Sekolah kejuruan yang ideal untuk abad 21}

Kebijakan-kebijakan di SMK pada umumnya menerapkan jadwal pelaksanaan kegiatan prakerin, baik dalam maupun ke luar negeri adalah pada saat seorang siswa berada di tingkat atau kelas 2 dan sebagian kecil lagi di kelas 3 awal tahun ajaran baru (Akhmad,2009). Sangat kurang sekali waktu yang dipergunakan siswa untuk mengenali dunia kerjanya, padahal muara dari sekolah 
kejuruan adalah dunia kerja. sistem ini merupakan pemborosan waktu (inneffective and inefficient) karena penyelenggaraan pembekalan keterampilan melalui pendidikan formal bisa dimulai sejak tingkat SMP, dengan identifikasi kompetensi pada jenjang Sekolah Dasar. Pendidikan sebagai wahana pembentuk peradaban harus menggunakan 3 jalannya sesuai dengan porsinya (pendidikan formal, pendidikan non-formal, dan pendidikan informal) dengan yang menjadi starter adalah pemerintah. Pemerintah sebagai otoritas dari sebuah penyelenggaraan suatu negara harus dapat mengambil suatu kebijakan secara legal-formal, memberi ruang untuk suatu mediasi dalam mensinergikan tiga pilar pembangunan, yaitu : a) Pendidikan, b) Dunia usaha dan industri (DUDI) c) Pemerintah. (Bambang,2011).

\section{Urgensi pendidikan vokasional tingkat SMP}

ASEAN Community akan diselenggarakan pada tahun 2015, sebagai implikasinya akan terjadi liberalisasi pasar, artinya terdapat kebebasan keluarmasuk investasi, tenaga kerja dan produk dalam suatu negara. Pemerintah sudah menyiapkan infrastruktur dan kebijakan ekonomi, hal ini cukup baik namun hanya bermanfaat untuk manusia yang hidup pada masa itu. Kunci keberhasilan dalam memanfaatkan kondisi strategis Indonesia adalah persiapan manusianya yang antisipatif dan produktif, sehingga Indonesia bukan menjadi laboratorium percobaan bagi pemasaran produk asing. Sering kali yang menjadi langkah pertama pemerintah adalah kebijakan dibidang ekonomi, padahal kalau kita kaji lebih jauh sejatinya yang menjadi penentu kemajuan bangsa adalah pemuda dan kreativitasnya yang bersifat continue (karena diwariskan antar generasi).

Selain untuk mengimbangi liberalisasi pasar, langkah ini juga untuk memanfaatkan bonus demografi. Untuk menjadikan Indonesia sebagai negara yang memiliki tenaga ahli berkualitas dan berkuantitas, maka sektor pendidikan vokasional dan pendidikan tinggi harus mendapat perhatian khusus. Pendidikan tinggi sudah cukup mandiri dengan pola pikir perubahannya, sehingga pendidikan vokasional menjadi satu satunya fokus perhatian untuk menghasilkan SDM berkompeten. 
Pola pendidikan vokasional yang dimulai sejak SMP akan memberikan waktu belajar lebih lama bagi siswa tentang potensinya dan memberi kesempatan untuk mendalami kualifikasinya. Yang perlu diperhatikan dalam penyelenggaraan pendidikan ini adalah sistem PSG yang dijalankan. Semakin lama belajar maka akan semakin ahli dan kreatif seorang individu (learning by doing). Byram dan Wenrich (1956:50) sebagainama dikutip Rasto, bahwa "vocational education is teaching people how to work effectively”.

\section{Pihak-pihak yang berperan aktif dalam pengimplementasian}

Dalam pelaksanaan pola pendidikan ini perlu melibatkan 2 komponen pokok yang meliputi komponen statis dan dinamis. Komponen statis adalah komponen yang bisa memberikan efek mengikat dan menjadi sebuah hal yang dijadikan acuan / lamdasan, komponen tersebut meliput; pemerintah, sekolah, dan perusahaan (swasta maupun BUMN). Sedangkan komponen dinamis adalah semua lembaga pendidikan non formal dan informal. Lembaga pendidikan yang dinamis ini akan mengalami perubahan pola pikir dan tingkah laku sebagai respon atas kebijakan atau ketetapan dari komponen statis. Misalnya, begitu pemerintah sudah mewajibkan pendidikan vokasional ditingkat pendidikan menengah pertama, maka masyarakat dan keluarga akan mendukung program tersebut dan lebih optimis akan kemapanan / masa depan dari anaknya. Dengan demikian kebijakan yang dikeluarkan pemerintah dan peluang tenaga kerja dan perusahaan akan mendapat dukungan sosial maupun materi.

\section{Langkah strategis pengimplementasian}

Konsep penyelenggaraan pendidikan vokasional ini merupakan percepatan pendidikan yang mengacu pada keadaan gobal saat ini yang membutuhkakn tenaga ahli untuk mengolah sumber daya yang dimiliki. Adapun tahap - tahap pelaksanaan adalah sebagai berikut:

1.) Pengesahan Kebijakan

Tahap ini adalah yang paling sentral dalam alur yang akan dijalani, selama kebijakan pendidikan ini belum disahkan maka selama itu pula pola pendidikan 
tidak bisa dijalankan, sekolah tidak berani menjalankan pendidikan vokasional tanpa ada landasan hukum yang jelas.

2.) Perjanjian kerjasama pihak sekolah dan pihak perusahaan mengenai PSG.

Vocational education merupakan pendidikan dengan intensitas praktik / pengalaman lapang yang lebih banyak dan intensif, dengan tujuan spesifik menurunkan siswa ke lapangan sebagai media perkenalan terhadap dunia kerja. Tujuan dari PSG adalah memantapkan materi yang sudah dipelajari secara teori melalui praktik, nah untuk mendapatkan para ahli berkompeten, maka Pendidikan Sistem Ganda perlu dijalankan selama siswa menjadi siswa magang disebuah perusahaan. Perjanjian yang dimaksud ini adalah perjanjian yang memiliki dasar hukum yang kuat, sehingga regulasinya jelas. Secara praktik, sekolah memberikan daftar perusahaan yang akan dijadikan tempat magang kepada pihak berwenang (kementrian perindustrian dan perdagangan) sehingga nantinya setelah disetujui oleh pihak berwenang perusahaan tidak akan menolak adanya siswa magang yang akan mengaplikasikakn ilmunya. Kelemahan dari sistem PSG kita adalah perusahaan kurang memiliki perhatian dunia pendidikan, padahal pendidikanlah yang akan membangun perusahaan mereka. Berbeda dengan pendidikan vokasional di Jerman, pendidikan vokasional di Jerman mendapat intervensi perusahaan swasta maupun negeri, sehingga pendidikan vokasional disana maju karena siswa mendapat kesempatan yang lebih luas untuk mengekplorasi kemampuannya. Mereka mengizinkan siswa magang untuk memperdalam teori melalui praktik dan mengembangkannya (leraning by doing).

3.) Seleksi kompetensi di jenjang Sekolah Dasar.

Merupakan tahap untuk mengetahui kualifikasi apa yang dimiliki siswa yang nantinya menjadi landasan rekomendasi jurusan yang akan diambil dalam tingkat pendidikan menengah pertama sebagai langkah awal pengembangan kompetensi.

4.) Implementasi pola pendidikan

Tahap ini adalah tahap inti, dimana dalam tahap ini akan diselenggarakan pola pendidikan vokasional dengan mengacu pada efektifitas dan efisiensi belajar dan berorientasi pada pengembangan hard skill maupun soft skill. 


\section{a. Pendidikan Sistem Ganda.}

Dalam implementasi yang paling berpengaruh adalah pelaksanaan Pendidikan Sistem Ganda. Pelaksanaan PSG yang sebelumnya hanya dilakasanakan pada kelas 2, kini harus dilaksanakan sejak kelas 1 semester 2. Semester 1 merupakan pengenalan / orientasi siswa terhadap dunia sekolah yang berorientasi pada job market, kemudian pada semester 2 dan seterusnya merupakan pendidikan formal (teori) yang sebagian dalam pelaksanaannya adalah PSG. Artinya dalam satu hari sekolah, sebagian merupakan pelajaran formal (teori) dan setengahnya lagi adalah magang, dengan demikian materi yang dipelajari siswa bersifat aplikatif-langsung. Pola pengajaran seperti ini akan memperbaiki kualitas siswa vokasional (penerapan learning by doing every day).

\section{b. Ujian (assesment).}

Ujian-ujian semester bahkan ujian nasional sekalipun harus dengan keterlibatan pihak perusahaan karena secara langsung maupun tidak mereka juga melakukan penilaian terhadap kinerja siswa. Sehingga nantinya kredibilitas dan integritas yang dimiliki siswa akan terjaga, implikasi tehadap perusahaan adalah kapabilitas perusahaan juga akan terjamin. Perbandingan porsi soal ujian tulis dan praktik adalah 30:70. Melalui intervensi pihak perusahaan dalam assesment, dan porsi ujian praktik yang lebih banyak, maka pihak perusahaan akan dapat memberikan peluang siswa menjadi tenaga ahli disana, namun perusahaan tidak boleh memaksakan siswa menjadi tenaga tetap karena mereka punya kewajiban untuk melanjutkan studi. Secara tidak langsung hasil ujian siswa akan menentukan ketersedian lapangan kerja bagi siswa, inilah yang dimaksud keterjagaan atas kredibilitas dan integritas siswa.

\section{c. Sekolah lanjutan.}

Menemupuh pendidikan vokasional ditingkat SMP bukan berarti tidak melanjutkan sekolah lagi setelah lulus, justru siswa akan mendapat rekomendasi dari sekolah untuk melanjutkan studi ke SMK yang tidak atau sudah dianjurkan. Pada tingkat pendidikan menengah atas ini siswa akan 
diberikan pembekalan mengenai perkembangan dan kebutuhan masyarakat industri dunia, perkembangan teknologi mutakhir dunia dan antisipasi serta cara pengoperasiannya, sedangkan di tingkat pendidikan tinggi mereka akan dituntut untuk membuat penemuan-penemuan berupa alat yang solutif, tepat guna, dan ramah lingkungan. Nah disinilah point atas tenaga ahli yang dibutuhkan oleh dunia industri abad 21 akan terlihat dan terasa. Pada dasarnya manusia yang disebut sebagai tenaga ahli sudah dapat tercetak ketika mereka masuk ke SMK, karena disitu sudah mendapat pembekalan atas perkembangan masysrakat industri, teknologinya, dan cara pengoperasiannya (pengoperasian yang dimaksud termasuk pengembangan). Tenaga ahli yang dimaksud dalam pendidikan tinggi adalah mereka yang mampu menciptakan teknologi baru dan belum pernah ada.

\section{5.) Evaluasi program}

Evaluasi secara sempurna dan menyeluruh terhadap program yang dijalankan ini membutuhkan waktu yang realtif lama, karena membutuhkan satu kali siklus yaitu 6-10 tahun. (3 tahun di tingkat pendidikan menengah pertama, dan 3 tahun di tingkat pendidikan menengah atas, adapun 4 tahun selanjutnya merupakan pendidikan tinggi). 


\section{SIMPULAN DAN SARAN}

\section{Simpulan}

Pendidikan vokasional adalah pendidikan yang menitikberatkan aktivitasnya pada pembekalan keterampilan siswa yang berorientasi pada praktik dan mengacu pada kebutuhan masyarakat industri. Objek studi yang menjadi bahan kajian dalam pendidikan vokasional adalah perkembangan teknologi dan kebutuhan masyarakat industri. Terjadi penetrasi tenaga kerja antar negara dan derasnya arus globalisasi berbanding lurus dengan kemutakhiran teknologi yang membutuhkan tenaga ahli dalam pengelolaan teknologi.

Jika melihat pola pendidikan vokasional sekarang dan tantangan perkembangan teknologi, maka pola pendidikan vokasional yang sekarang masih belum sanggup untuk memenuhi tuntutan global. Untuk itu diperlukan sistem yang dapat mempercepat perbaikan kualitas secara efektif dan efisien. Upaya tersebut dapat diwujudkan dengan menjalankan pola pendidikan vokasional yang dimulai sejak tingkat pendidikan menengah pertama. Berikut diagram alir yang menggambarkan pola pendidikan vokasional yang dimaskud :

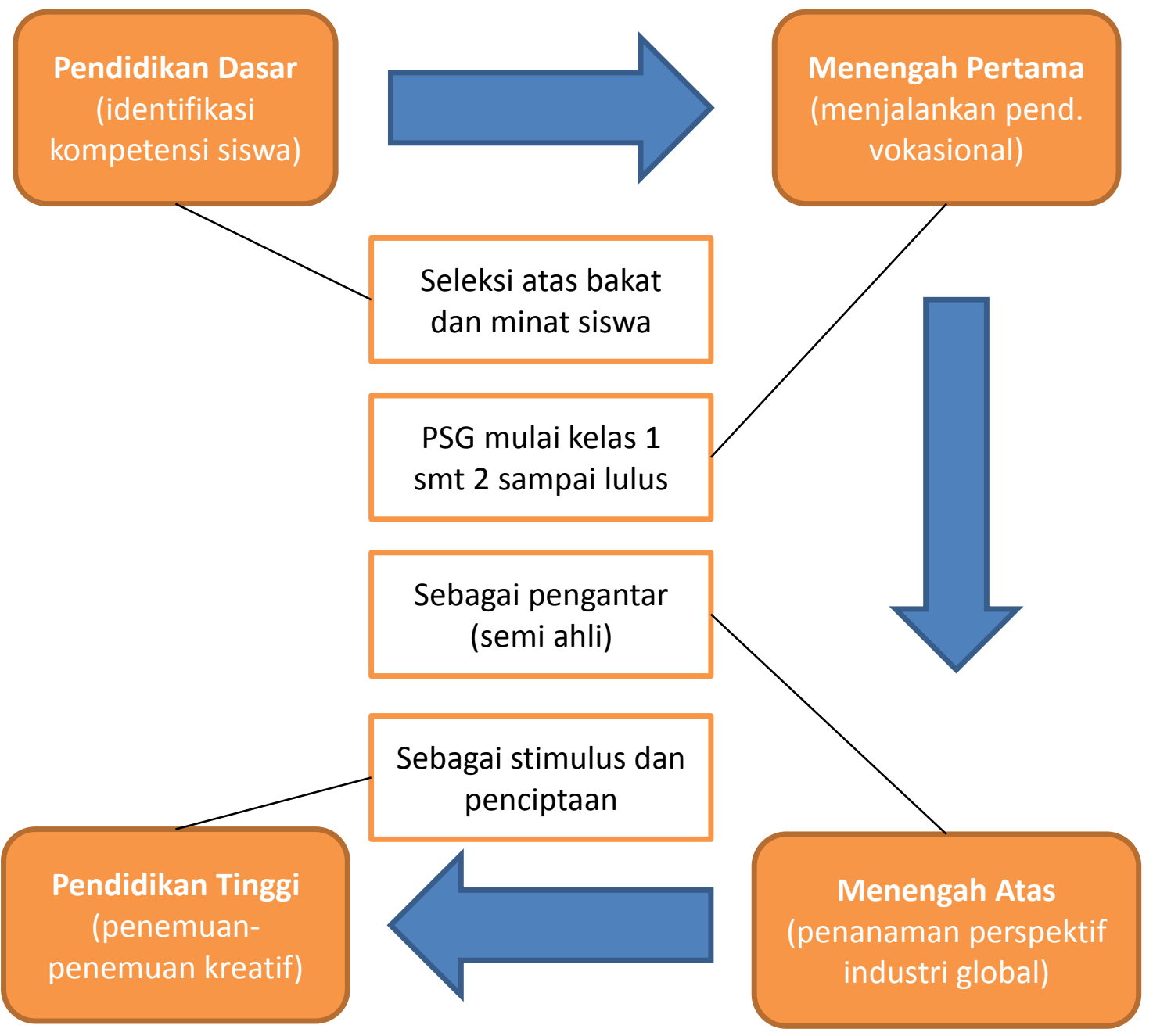


Melalui pola pendidikan seperti ini maka Indonesia bisa menjawab tantangan ASEAN Community yang menghadirkan penetrasi tenaga kerja asing, tantangan liberaliasasi pasar internasional, terkelolanya sumber daya alam yang dimiliki Indonesia oleh tuan rumah sendiri, dan termanfaatkannya bonus demografi yang sedang dialami Indonesia dengan bijak, sehingga Indonesia menjadi berdikari dan tidak ragu atas investasi asing dan penetrasi lainnya karena SDM Indonesia sudah antisipastif dan kondusif.

\section{Saran}

Dari kesimpulan sudah jelas bahwa melalui pendidikan vokasional sejak tingkat SMP akan mempercepat terciptanya tenaga ahli di Indonesia. Tenaga ahli ini untuk mengolah segala sumber daya dalam negeri, melakukan penemuan penemuan baru yang solutif bagi masyarakat, dan meningkatkan pertumbuhan ekonomi. Untuk itu ada 3 pihak yang harus bersinergi menjalankan pola ini, yaitu perusahaan, pemerintah dan masyarakat. 


\section{DAFTAR PUSTAKA}

Hamid, Abdulloh. (2013). Penanaman Nilai-Nilai Karakter Siswa SMK Salafiyah Prodi TKJ Kajen Margoyoso Pati Jawa Tengah. Jurnal Pendidikan Vokasi, 32, 141.

Karyono, Akhmad. (2009). Kontribusi Status Industri Tempat Prakerin, Lama Prakerin, Dan Motivasi Belajar Terhadap Sikap Kewirausahaan Siswa SMK di Kabupaten Indramayu. Teknologi dan Kejuruan, 32, 168.

Putra, Aditya Indra. (2009). Pengaruh Pengalaman Praktik Kerja Industri Terhadap Minat Berwirausaha Pada Siswa Kelas XII Program Keahlian Teknik Mekanik Otomotif SMK Texmaco Pemalang. Jurnal PTM, 9, 1.

Rasto. (2012). Pendidikan Kejuruan. Bandung : Universitas Pendidikan Indonesia.

Sugestiadi, Bambang. (2011). Pendidikan Vokasional Sebagai Investasi. Yogyakarta : Universitas Negeri Yogyakarta.

Yunus, Yuhanis. (2013). Peningkatan Sumber Daya Manusia Indonesia Melalui Pendidikan Vokasi, 9. Lhokseumawe : Politeknik Negeri Lhokseumawe. 